\title{
Robert Papieski
}

MuZEum IM. A. I J. IWASZKIEWICZÓW w STAWISKU

e-mail: r.papieski@stawisko.pl

(iD https://orcid.org/0000-0001-7051-7054

\section{Pogrzeb królowej Jarosława Iwaszkiewicza - opracowanie edytorskie}

\section{Abstract \\ The Funeral of the Queen by Jarosław Iwaszkiewicz - Editing the Text}

The article mainly quotes a previously unpublished manuscript of Jarosław Iwaszkiewicz's novel about Bona Sforza, entitled The Funeral of the Queen, which he has worked on between the 6th of June 1949 and 1953. The editor presents the origins of the book and its development. Additionally, all documents that Iwaszkiewicz researched and collected while working on the novel are included in the book, including notes, nine versions of the first sentence of the novel, and the letters from Ludwik Kolankowski and Zofia Zarembianka, who provided Iwaszkiewicz with factual information. The conclusion of the article reveals the nature of Iwaszkiewicz's writing, showing that a huge amount of documents he researched - instead of helping him - paralysed him.

Key words: Bona Sforza, Jarosław Iwaszkiewicz, Stawisko, Barbara Radziwiłłówna, manuscript

Słowa kluczowe: Bona Sforza, Jarosław Iwaszkiewicz, Stawisko, Barbara Radziwiłłówna, rękopis 
Pogrzeb królowej to jeden z tych kilkunastu projektów literackich Jarosława Iwaszkiewicza, który nigdy nie doczekał się pełnej realizacji. Najgłębszych jego korzeni wolno doszukiwać się we wczesnym dzieciństwie autora, kiedy miał około sześciu lat i mieszkał w Kalniku na ukraińskim Podolu. Pisarz wspomina:

Za stołowym pokojem w Kalniku był pokój moich sióstr. Odznaczał się tym, że miał szerokie, tak zwane weneckie okno i wymalowany był na niebiesko czy na szaro, tak jak ściany niektórych chat. W pokoju tym stały dwa łóżka jedno po prawej stronie od wejścia, drewniane, szerokie, gdy nastawała pora zmierzchu, dwie siostry mogły się tu położyć. Śpiewały, jak nieraz to już wam mówiłem. Ale także mówiły. Opowiadały o Krakowie. [...] o krakowskim teatrze: jakbym tam był, jakbym widział Bonę, Zygmunta Augusta i nieszczęsną królową Barbarę (Iwaszkiewicz 1983: 51).

Jednak bezpośrednią inspiracją był dla Iwaszkiewicza obraz Józefa Simmlera Śmierć Barbary Radziwiłłówny, wiszący w gabinecie pisarza od czasu wprowadzenia się Iwaszkiewiczów na Stawisko, czyli od roku 1928 (Iwaszkiewicz 1977: 156). Ilekroć Iwaszkiewicz zasiadał za biurkiem, omiatał wzrokiem płótno Simmlera, stanowiące replikę dzieła z 1860 roku, wiszącego w Muzeum Narodowym w Warszawie. Jedną z dwóch replik Śmierci Barbary Radziwiłłówny, namalowanych przez Simmlera, kupił fabrykant, a zarazem mecenas i kolekcjoner sztuki Stanisław Lilpop, który przekazał obraz w spadku swojemu synowi, a teściowi Iwaszkiewicza, Stanisławowi Wilhelmowi Lilpopowi, ten zaś polecił zawiesić płótno w gabinecie swojego zięcia.

Trzeba jednak było dwudziestu jeden lat, by mglista chęć literackiego opracowania tematu śmierci Barbary Radziwiłłówny przeobraziła się w realizację zamysłu - co prawda częściową tylko, bowiem z materiałów zebranych przez Iwaszkiewicza podczas przygotowań do pisania powieści Pogrzeb królowej wynika, że pisarz przystąpił do pracy nad nią 6 czerwca 1949 roku, gdyż tę właśnie datę postawił pod dziewięcioma wariantami pierwszego zdania Pogrzebu królowej. Nazajutrz napisał list do profesora Ludwika Kolankowskiego z prośbą o pomoc w zebraniu materiałów o królowej Bonie. Nawiązał też kontakt z historykiem Władysławem Pociechą.

Rozmiar - a może należałoby raczej powiedzieć: rozmach - nadesłanych przez historyków bibliografii nie tylko zamienił Iwaszkiewicza w pilnego czytelnika tekstów historycznych, ale też go sparaliżował jako pisarza, który do tej pory czerpał inspirację przede wszystkim z własnego życia, a jeśli z lektur poświęconych jednemu tematowi, to jednak nieczytanych tak gruntownie i w takiej liczbie. Uwaga ta dotyczy również powieści historycznej Czerwone tarcze (1934), którą Iwaszkiewicz napisał językiem współczesnym, co często poczytywano mu za zasługę, a co mogło być efektem obrania łatwiejszej metody pisarskiej, niewymagającej żmudnych studiów nad staropolszczyzną. W wywiadzie udzielonym Adamowi Galisowi krótko po ukazaniu się Czerwonych tarcz Iwaszkiewicz nawet nie potrafił precyzyjnie wskazać 
przyczyny napisania tej powieści, jakby jej geneza tkwiła tam, gdzie rodzą się wiersze - w stanie ducha autora, w jego nieświadomości, w osobistych sympatiach:

- [A. G.:] Jak się przesuwa w pisaniu ów „rygielek” między prozą a poezją?

- [J. I.:] Nie piszę nigdy równocześnie wierszem i prozą. To jest niemożliwe. Dlatego po kolei, po tomie wierszy następuje tom prozy.

- [A. G.:] A pobudki pisarskie? Dlaczego Czerwone tarcze?

- [J. I.:] Po napisaniu książki zapominam o pobudkach. Może na podstawie listów lub notatek mógłbym zrekonstruować pobudki. A zresztą trudno się teraz, po napisaniu książki, przenieść w atmosferę pomysłu. To wszystko odbywa się przecież przy przewadze rzeczy nieświadomych.

- [A. G.:] Czy jednak poza tą mistyką twórczości nie może pisarz ustalić konkretnych punktów zaczepienia z tym, a nie innym tematem czy problematem? - [J. I.:] Jeżeli chodzi o Czerwone tarcze, to możliwe, że stało się to jeszcze podczas nauki historii. Na Henryka Sandomierskiego zwraca uwagę Smolka w jednej ze swych książek jako na postać romantyczną. Przyczyniło się może również do wyboru tego tematu moje zainteresowanie dla średniowiecza [...]. - [A. G.:] [...] Ale dlaczego się Henrykowi Sandomierskiemu nie powiodło?

- [J. I.:] Rozstrzygnięcie w powieści jest negatywne dlatego, że mam zamiłowanie do słabego człowieka, do jego psychologii, interesuje mnie to, dlaczego stał się słaby. Ten sam motyw jest w Zmowie mężczyzn - problemat rozpraszania się słabych ludzi, charaktery zdezorganizowane. Decyduje o tym we mnie wrodzony liryzm i sympatia do słabego charakteru. Sam jestem immanentnym pesymistą.

- [A. G.:] Symboliczna scena, kiedy Henryk przejeżdża z brzegu na brzeg, nie mogąc powziąć decyzji...

- [J. I.:] Tak. A proszę zaznaczyć, że scena ta napisana jest pod wpływem powieści pisarza duńskiego Johannesa V. Jensena, pt. Upadek króla (Galis 1934: 978).

Nie ulega wątpliwości, że po napisaniu Pogrzebu królowej Iwaszkiewicz nie mógłby udzielić tak enigmatycznych odpowiedzi na temat jego genezy i faz pracy - być może dlatego Pogrzebu królowej nie napisał. Temat od początku nastręczał trudności. 31 marca 1950 Iwaszkiewicz zanotował w dzienniku:

[...] przystępując do jakiegoś pisania, gdy zaczynam sobie wyobrażać, ile mam jeszcze napisać, zanim dojdę do końca, porywa mnie strach i nuda i przestaję pisać. Stąd tyle ostatnio rzeczy niedokończonych, ledwie pomyślanych: Młyn nad Łukawq, Pogrzeb królowej, Małżeństwo Pryscylli. Na tym zapewne polega starcza niemoc, to samo zapewne w dziedzinie erotycznej (Iwaszkiewicz 2007: 307).

131

Fabrica Litterarum Polono-Italica | 2020, nr 1 (2) 
By przezwyciężyć twórczą niemoc, Iwaszkiewicz w końcu października 1950 roku pojechał do Krakowa:

Podróż moja do Krakowa miała znaczenie literackie - pisał w liście z 1 listopada 1950 do córki Teresy - przygotowania do tej powieści z XVI wieku, o której, zdaje się, już kiedyś tobie mówiłem. W związku z tym miałem ogromną rozmowę z dr. Pociechą, ostatnim kochankiem królowej Bony, jak go nazywają, który mi naopowiadał mnóstwo szczegółów o ludziach szesnastego wieku, o których mówi jak o swoich dobrych znajomych i o których zna wszystkie ploty (Iwaszkiewicz 2009: 263).

Tego samego dnia pisał w liście do Jerzego Lisowskiego: „siedzę po uszy w polskim XVI wieku (był to jeden z powodów wyjazdu do Krakowa) dla mojej nowej powieści, której zarys już widzę, a nawet parę zasadniczych scen (rozmowa Bony z Zygmuntem Augustem podczas pogrzebu Barbary)"1.

Na półtora roku kwestia pisania Pogrzebu królowej zeszła na dalszy plan, Iwaszkiewicz nie wspomina o tym w dzienniku, w notesach czy listach. Zamiar pisania powieści o Bonie wrócił w maju 1952 roku, gdy pisarz wyjechał do Sandomierza. W kalendarzu 31 maja 1952 roku zanotował: „Plany sandomierskie: Pogrzeb królowej, O Nałkowskiej +, Sztuka, Opowiadania +, Przeczytać Nerudę +, pamiętniki +"22. Jak widać, Pogrzeb królowej miał kilku „rywali”: przemówienie o Zofii Nałkowskiej, przygotowywane na jubileusz 50-lecia pracy twórczej pisarki, który odbył się 4 czerwca 1952 (zatytułowane Do Zofii Nałkowskiej), zostało ogłoszone w książce Iwaszkiewicza Cztery szkice (1954); tłumaczenie sztuki Szekspira Romeo i Julia (Romeo i Julia. Hamlet, tłum. Jarosław Iwaszkiewicz) ukazało się w 1954; pisanie opowiadań: Fama („Twórczość” 1956, nr 6) oraz Dziewczyna i gołębie („Twórczość” 1955, nr 3); czytanie tłumaczenia poematu Canto general Pabla Nerudy (przekładu z języka hiszpańskiego dokonali Konstanty Ildefons Gałczyński, Jarosław Iwaszkiewicz, Lech Pijanowski, Janusz Strasburger; książka pt. Pieśń powszechna ukazała się pod redakcją i ze wstępem Iwaszkiewicza w 1954 roku); trudno natomiast orzec, o jakich pamiętnikach jest mowa - w dzienniku 1 czerwca 1952 Iwaszkiewicz odnotował: „dużo przeczytałem samych pamiętników, co mnie trochę napełniło jakąś starczą atmosferą" (Iwaszkiewicz 2007: 407).

Tego samego dnia, 1 czerwca 1952, Iwaszkiewicz informował w liście Jerzego Lisowskiego: „do Pogrzebu królowej, ściślej mówiąc do sceny Zygmunta Augusta z Boną, boję się przystąpić, potwornie odpowiedzialny temat" ${ }^{3}$. A nazajutrz za-

1 List znajduje się w archiwum Muzeum im. Anny i Jarosława Iwaszkiewiczów w Stawisku.

2 Kalendarz na rok 1952 znajduje się w archiwum Muzeum im. Anny i Jarosława Iwaszkiewiczów w Stawisku.

3 List znajduje się w archiwum Muzeum im. Anny i Jarosława Iwaszkiewiczów w Stawisku.

132 
pisał w kalendarzu: „Wieczór: Zygmunt I i Z. II” - co prawdopodobnie oznacza: Zygmunt I Stary i Zygmunt II August.

Z listu do Wiesława Kępińskiego z 18 lipca 1953 roku wiadomo, że Iwaszkiewicz jeszcze nie porzucił myśli o napisaniu powieści o królowej Bonie: „w niedzielę mam bilety na premierę nowej sztuki Auderskiej w Teatrze Narodowym - o Zygmuncie Auguście, Barbarze, Bonie itd. Bardzo jestem tego ciekawy ze względu na moją Bonę (Pogrzeb królowej)" (Iwaszkiewicz, Kępiński 2014: 259). Autor listu ma tu na myśli dramat historyczny w trzech aktach Haliny Auderskiej Rzeczpospolita zapłaci w reżyserii Józefa Wyszomirskiego, wystawiony 19 lipca 1953 roku.

To ostatni ślad pracy nad Pogrzebem królowej, wróci do tego zagadnienia Iwaszkiewicz w połowie lat siedemdziesiątych, gdy będzie pisał za serdeczną namową Pawła Hertza Podróże do Włoch. W rozdziale zatytułowanym Bari wyzna wówczas:

Do Bari wybierałem się od dawna i wielokrotnie. Parę razy wyjazd do Bari był dla mnie pretekstem do uzyskania paszportu do Włoch. Powiadałem wtedy odnośnym władzom, a nawet wyłuszczałem to na piśmie, że pracuję nad powieścią o królowej Bonie i że niezbędne jest dla mnie z tego powodu odwiedzenie jej grobu. Parę razy jechałem do Włoch z tym zamiarem, ale jakoś do Bari nie mogłem dojechać. Nawet pod tym pretekstem odwiedziłem kiedyś w Krakowie profesora Pociechę i otrzymałem od niego w prezencie dwa pierwsze tomy jego pracy o królowej Bonie. Zamiar mój był zbożny i nie blagowałem. Rzeczywiście zacząłem pisać powieść czy dłuższe opowiadanie, które nigdy nie wyszło poza pierwsze dwie strony. Opowiadanie miało się nazywać Pogrzeb królowej i treścią jego miał być opis pogrzebu Barbary Radziwiłłówny, który ciągnął się przez wiele tygodni idąc z Krakowa do Wilna, przy czym Zygmunt August szedł piechotą za karawanem wiozącym zwłoki królowej. Temat ten, zapewne natchniony obrazem Simmlera, który wisi u mnie w gabinecie, prześladował mnie czas dłuższy. Wreszcie oceniając, że moje przygotowanie historyczne jest zbyt skąpe, abym mógł nakreślić tak wielki obraz tego przeżycia, a jednocześnie przemierzanej przez Zygmunta Augusta Polski, pomysłu zaniechałem, czego nieco żałuję. Do poznania królowej Bony solidnie się przygotowywałem i trochę nawet ją poznałem, przywiązałem się do niej; nie uważałem jej za kobietę zbyt inteligentną, choć oczywiście była to indywidualność o mocnym, zbyt mocnym charakterze.

Przygotowując się do tej pracy i ciągle wracając myślą do włoskiej królowej, poruszyłem wielkie powagi historyczne, profesorów Kolankowskiego i Pociechę. Profesor Ludwik Kolankowski w odpowiedzi na list skierowany do niego udzielił mi pożytecznych wskazówek i błogosławił na napisanie "arcydzieła", "klejnotu wydobytego z głębi duszy", a Pociecha, po mojej wizycie u niego w Bibliotece Jagiellońskiej, przesłał mi przez swą sekretarkę czy uczennicę wyczerpującą bibliografię przedmiotu. Obawiam się, że właśnie ta niezmiernie szczegółowa bibliografia, a także przeczytanie takich książek, jak Królowa Bona

133

Fabrica Litterarum Polono-Italica | 2020, nr 1 (2) 
Pociechy, Czasy Zygmuntowskie na tle prq̨ów Odrodzenia Morawskiego czy Jagiellonki polskie Przeździeckiego zniechęciły mnie do ogromu tego przedsięwzięcia. Przymierzałem się do niego jednak jak nigdy, czego dowodem jest dziewięciokrotny kształt, w jaki przyoblekałem pierwsze zdanie opowieści. Zapewne myślałem o słynnych z pism Tołstoja puszkinowskich: „Gosti sjezżalis na daczu” czy też „W domie Obłońskich wsio...” (Iwaszkiewicz 1977: 156-157).

Wszystko, co Jarosław Iwaszkiewicz zebrał w związku z pisaniem Pogrzebu królowej, mieści się w teczce oznaczonej symbolem AL/47, przechowywanej w archiwum Muzeum im. Anny i Jarosława Iwaszkiewiczów w Stawisku. Pierwsze karty zawierają rękopis utworu, następne - zgromadzone przez pisarza materiały. Poniższy ich układ stanowi odwzorowanie numeracji kart. Edytując je, nie ingerowałem w pisownię, nieliczne uwagi i uzupełnienia zawarłem w nawiasach kwadratowych. Objaśnienia włoskich słów, wyrażeń zaznaczam przypisami gwiazdkowymi.

\section{Karty 1-10}

\section{Pogrzeb królowej [rękopis, fragment zaznaczony na niebiesko posiada także wer- sję w maszynopisie]}

Królowa Barbara umarła na zamku w Krakowie dnia 8 maja 1551 roku. Komnata królowej znajdowała się w północnej części i przytykała do dawnych apartamentów królowej Jadwigi. Przy śmierci żony obecny był tylko król, ksiądz Podlodowski i pani Maciejowska. Służbę pełnił pokojowy Rdest Chęciński, który też zaraz po tym jak pani skonała uprowadził króla do jego pracowni. Był to pokój podłużny, przedzielony drewnianą arkadą i na stół królewski, na którym poniewierały się księgi, papiery i pióra, padał blask słońca i oddech poranku. Było koło godziny szóstej i poranne promienie miały ten szczególny majowy blask na pół żółty, a na poły różany. Król usiadł na zydlu przy stole, pochylił głowę i nie mówił ani słowa. Rdest widział złożone na łonie ręce królewskie, wąskie i żółte, bardziej trupie niż ręce królowej. Król wyglądał bardzo niedobrze, godziny czuwania i ranne modlitwy, wdychanie jadowitych wyziewów rozkładającego się żywota królowej pokryły jego rysy popiołem zmęczenia. Postarzał o wiele lat i w czarnej brodzie widniały pierwsze srebrne nitki. Zabłysły one w blasku słońca. Świegot ptactwa stał za oknami równy i ostry.

Rdest zatrzymał się przy drzwiach i nie wiedział, co ma robić, czy wyjść czy zostać. Król jak gdyby nie dostrzegał jego obecności. Wtem nagle bez żadnego opowiedzenia się, bez orszaku nawet, bez pachołka szybkim krokiem wszedł prymas Dzierzgowski. Na szelest jego szaty król otworzył oczy i spojrzał niechętnie. Długi prymas nagłym gestem upadł na kolana i przypadł twarzą do czarnej szaty królewskiej, wstrząsnął się w łkaniu. Król lekko odepchnął go od siebie.

- Stało się - powiedział cicho.

134

Fabrica Litterarum Polono-Italica | 2020, nr 1 (2) 
Dzierzgowski powstał i ukrył twarz w dłoniach. Tak chwilę trwało milczenie. Rdest mimo woli spojrzał przez okno, gdzieś zieleniły się stoki wawelskiego wzgórza i widać było szczyty rozrośniętych drzew: na jednym z nich to właśnie usiadła wilga i gwizdała zawzięcie. Pachołek spostrzegł jej złote pióra jak mieszały się z zielonymi, całkiem jeszcze świeżymi liśćmi dębu i z blaskiem słonecznych promieni.

Dzierzgowski odjął ręce od twarzy i uznał za stosowne powiedzieć królowi długą konsolację.

Kiedy orszak pogrzebowy przemierzając ubogie Podlasie zbliżył się do Sokołowa i król swoim zwyczajem zsiadł z konia, aby pieszo wejść za trumną do miasta, powiedziano mu, że z powodu niedawnego pożaru nie będzie mógł spędzić nocy w miasteczku i że przygotowano dla niego popas kilka stajań dalej, w stronę Bugu, niedaleko przeprawy, w karczmie żydowskiej, która tam wśród lasu stała. Ledwie więc ruszono dalej, nie wjeżdżając pomiędzy pogorzałe domy, dopadł króla goniec z Siedlec z pewną tajemną wiadomością. Król wzruszył ramionami na słowa posłańca i policzki jego jak zazwyczaj, jak jeszcze u króla Starego, okryły się rumieńcem. Wszyscy widzieli jego gest lekceważący i zniecierpliwiony i rozmaicie z tego powodu wnioskowali. Gdy dojechali do karczmy, kolaska ze zwłokami zatrzymała się przy drzwiach, wyprzęgnięto jak co wieczora konie - ale jeszcze przedtem król rozkazał, aby ją nieco od podjazdu odsunięto, jak gdyby chciał miejsce zostawić tu wolne. Król wszedł do przygotowanej komnaty, całej wybitej już tym wędrownym kirem, który wciąż jak właściciel nieszczęścia przed pogrzebem na rozstawnych koniach podążał. Król nie wieczerzał. Odesłał panów i pokojowych, ale Rdest widział, że się do łoża nie pokładł. W sieni szeptali przerażeni Żydzi, których na próżno od karczmy odpędzano, a Rdest siedzący u progu na zydlu słyszał, jak pan chodził po pokoju tam i z powrotem wolnym, zamyślonym krokiem.

Noc była ciepła, gorąca nawet, i okna komnaty były wszystkie otwarte. August słyszał, jak dworzanie poili konie u studni opodal, jak konie prychały i dzwoniły wędzidłami, jak powoli zacichały wszystkie odgłosy. Ogniska palono z daleka, na drodze i w lesie. Las ten ze wszystkich stron do karczmy podchodził i król wyzierając przez okna spostrzegał niewielką przestrzeń nieba pełną gwiazd i przezroczystą, otoczoną czarnymi masami drzew. Od czasu do czasu niewidzialnymi wierzchołkami przechodził nocny dreszcz i wzruszał powietrze. Z daleka gdzieś rechotały żaby. August często wyglądał przez okno. Woskowe świece w pokoju paliły się ciemnawo, trzaskając i sycząc. Tak trwało prawie do północy.

Około północy z daleka rozległ się tętent i turkot, który się gromko rozchodził po rosistej przestrzeni. Król stanął przy oknie i patrzył w stronę zachodnią, niebo tam, mimo północy, jak zwykle w czerwcu, nie traciło zielonawej jasności. Na drodze widać było zbliżające się nieliczne pochodnie. Poruszały się one szybko i widać było, że jeźdźcy wiozący je galopują. Prawie nagle szerokie liście klonów otaczających pomieszczenie podbiły się czerwonawym blaskiem i zwisały dziwnie wyraźne, jak

135

Fabrica Litterarum Polono-Italica | 2020, nr 1 (2) 
nieruchome zwierzęce łapy. Z nocy, w tym sztucznym blasku, wynurzyły się kare konie zaprzęgnięte do czarnej kolasy. Zygmunt August mimo woli ocenił ich wartość po cienkości ich pęcin przebierających w kurzu, który stał się raptem wyraźny i różowy. Konie były wspaniałe, już po tym samym poznałby wybór matki. Blask pochodni oświecał ich zadarte w górę głowy, czarne, duże grzywy i boki, z których płatami spadała ciężka piana. Zaryły one kopytami w ziemię, zatrzymując się przed gankiem. Zygmunt cofnął się do komnaty i stanął przy stole.

Przed karczmą rozległy się głosy, rozmodlony ton mowy Koszutskiego zabrzmiał jak odzew ptaka rozbudzonego w nocy, i oto August posłyszał na ganku i w sieni dźwięk kroków szybkich i energicznych, które w dzieciństwie już rozpoznawał pośród wszystkich kroków, a które go zawsze napawały miłością i lękiem.

Bona weszła do syna zupełnie sama. Ci, którzy jej towarzyszyli, zostali za progiem. W półcieniu Zygmunt ujrzał jej wysoką, krzepką i majestatyczną postać. Pomimo szlarek białego wdowiego czepca oczy jej zabłysły dawnym, aksamitnym, nieco szklanym, hiszpańskim blaskiem. Król słyszał, jakoby była całkiem złamana jego małżeństwem i nadzwyczaj się postarzała. Tymczasem teraz widział ją równie prostą i żywą jak za czasów dzieciństwa. Co prawda w zaciśniętych, zwężonych wargach rozpoznał pewne wysilenie: być może owa dawna moc i pewność siebie $w$ tej chwili była tylko maską. Nie widział jej od lat trzech czy czterech, a oto wchodziła do jego pokoju tak zwyczajnie i zamaszyście jak za lat dziecinnych na Wawelu czy na zamku wileńskim. I nim zdążył zrobić kilka kroków naprzód, pochylić się i przypaść do jej dłoni, poczęła mówić tym swoim dziwacznym językiem, szybką i wprawną polszczyzną przetykaną co chwila dziwacznymi, ale niesprawiającymi jej kłopotu błędami w liczbach, przypadkach i rozróżnieniach osobowych. Słów jej nie brakowało, ale od czasu do czasu wstawiała słowa łacińskie i włoskie.

- Koni byli doskonali - zaczęła - i byliśmy by przyjechali due ore fa*, ale pod koniec ta prawa okulawiła się, prawa licowa... wszystki moi podolski koni... tylko ta dyszlowa wolyński z Kremenec... mówi ci, koni jak złoto. Ty takich ni masz, koniuchy twoi niewiele warte...

Zygmunt nie mówił nic.

- Cóż tak stoisz? - ciągnęła - Każ matce co dać. Wstaliśmy wcześnie, z Warszawy wyjechali alle sei**, w Mińsku koni mieniali - non ho mangiato tutta la giornata***. Tysz się wybrałeś z tym pogrzebem. Dlaczegoś w Krakowie twojej coronaty**** nie pochował?

* Due ore fa (wł.) - dwie godziny temu.

** Alle sei (wł.) - o szóstej.

*** Non ho mangiato tutta la giornata (wł.) - nie jadłam cały dzień.

**** Coronata (wł.) - ukoronowana.

136

Fabrica Litterarum Polono-Italica | 2020, nr 1 (2) 
Zygmunt dotychczas pochylony wyprostował się sztywno. Usta mu się zacisnęły jak u matki, stał się do niej podobny. Klasnął $\mathrm{w}$ ręce i kazał Rdestowi podać dla matki wieczerzę. Wszystko już było zawczasu przygotowane.

- Dasz mi inni koni? - zapytała Bona - muszę jechać stamattina*.

- Siadajcie, matko - powiedział Zygmunt.

Bona zasiadła przy stole na ławce, tak że światło świec oświetlało jej twarz z dołu: spostrzegł, że była pożółkła i pomarszczona.

- Czegóż chcesz ode mnie - powiedziała nagle rozkładając ręce po stole uznałam ci ją za synową, list napisałam, te twoje ragazze** siostry pisały takoż. Czego chcesz?

Zygmunt usiadł i przeczekał, aż Rdest postawił przed Boną tacę z chlebem, serem, winem, gorącą piwną polewką. Gdy pokojowy wyszedł, ozwał się dopiero:

- Uznaliście, jak na urągowisko, na miesiąc przed śmiercią.

- A czy ja wiedziałam - upiła delikatnie polewki i postawiła srebrzony kielich, otrząsając się lekko ze wstrętem, polubiła już tę polewkę, a jeszcze się do niej nie przyzwyczaiła. - 0 tej chorobie tak różnie mówili.

- Od roku wiadomo było, że nie wytrzyma - powiedział Zygmunt. - Już w koronację zdrowa nie była.

- A coś ty sobie taką chorą wybrał? - Bona zaczęła ostro, jak do starosty, ale się nagle pomiarkowała. - I znowu jesteś bez dzieci.

- Samiście mi także chorą wybrali.

- Ja nie wybierałam. Wiesz dobrze, król Stary wybierał, chciałam dla ciebie skądinąd żony. Niemców nigdy nie lubiłam.

- Ja wiem, matko - spokojnie i głęboko powiedział Zygmunt. Matka podniosła na niego oczy i pierwszy raz popatrzyła na niego uważnie.

- Ale zmieniłeś się - szepnęła - poczerniałeś na twarzy. Ta droga musi cię męczyć.

- Męczę się długo - powiedział z uśmiechem - ale królowie męczą się od urodzenia.

- Miałeś być szczęśliwy - powiedziała Bona, smarując chleb masłem.

- Król Stary był szczęśliwy - westchnął Zygmunt.

- Tak - powiedziała szybko Bona - ale on nie rozumiał, co to jest nowe życie. On nic nie rozumiał. Litwa to dla niego był folwark dziedziczny, a Polska folwark dzierżawny. On nie rozumiał, co to jest państwo.

- I ty, matko, jakoś opacznie to państwo rozumiesz.

- Chciałabym, abyś ty tak rozumiał jako i ja. Nie marnowałbyś wtedy zdrowia i czasu... na amory.

* Stamattina (wł.) - dziś rano.

** Ragazze (wł.) - dziewczęta.

137

Fabrica Litterarum Polono-Italica | 2020, nr 1 (2) 
Zygmunt surowo powiedział:

- Matko! - Zamilkła.

Wstał od stołu.

Rozgwar obozu wokół karczmy zamilkł. Gwiazdy zasnuły się welonami i ciepło przesiąkało wilgocią. Ogniska się dopalały i dym szedł od nich gęściejszy. Żaby jednak nie przestawały rechotać, choć już czuć było w powietrzu letnie świtanie. Zygmunt usiadł na oknie, zwieszając cienkie nogi odziane w czarny trykot.

- Mówiłam ci tyle razy - powiedziała Bona - nigdy nie trzeba odwracać się plecami do drzwi i okien.

- Co mi tam - powiedział Zygmunt.

- Właśnie. Ciebie obchodzi tylko własne życie. A kraj?

Zygmunt machnął dłonią. Bona skończyła jeść, wytarła usta serwetką haftowaną złotem i odsunęła tacę. Oparła głowę na dłoni. Zaczęła mówić, jakby marzyła, jakby przypominała. Mówiła nocne słowa.

\section{Materiały do Pogrzebu królowej}

\section{Karta 10}

Dzierzgowski

ważne!!!

Koszutski z Pierzchna (wielkopol.)

Cyceron $O$ powinnościach wszech stanów ludzi

Baliński Pamiętniki o królowej Barbarze

\section{Karta 11}

Wspomnienie przyjęcia w Sandomierzu 1545

Zapalenie „wulkanu”

Za trzewiczki z perłami Smoleńsk trzeba było oddać

Koronacja i do trumny - szaty kościelne

Krew z piwa, nieburzliwa (Bona)

Stu rękami

Skulte

Epilepsja Elżbiety Rak.

138

Fabrica Litterarum Polono-Italica | 2020, nr 1 (2) 
Dla powietrza król po wioskach bawi (1547)

Piotr Zborowski

Lepiej z okna wyglądać niż z wież

\section{Karta 12}

Sapieha Iwan

Hlebowicz Jan

Achacy Czema (Bałtyk)

bisk. Samuel Maciejowski $(\mathrm{H})$

Jan Tarnowski

Olbracht Łaski (W)

str. 304 (Kolanek)

Hozjusz!! (Kol. 306)

Co nam każdemu potrzeba, trochę płótna i ziemi na 3 łokcie.

8 maja (8go?) śmierć

23 maja rusza kondukt

Tatarzy

19 lipca układ Izabeli [Jagiellonki]

Na odwrocie:

Jerzy Radziwiłt

Mikołaj Rudy

Barbara

1/ Gaszt.[ołd] Stan[isław]

2/ Zygm. Aug.
Jan Ra[dziwiłł]

Mikołaj Czarny

\section{Karta 13}

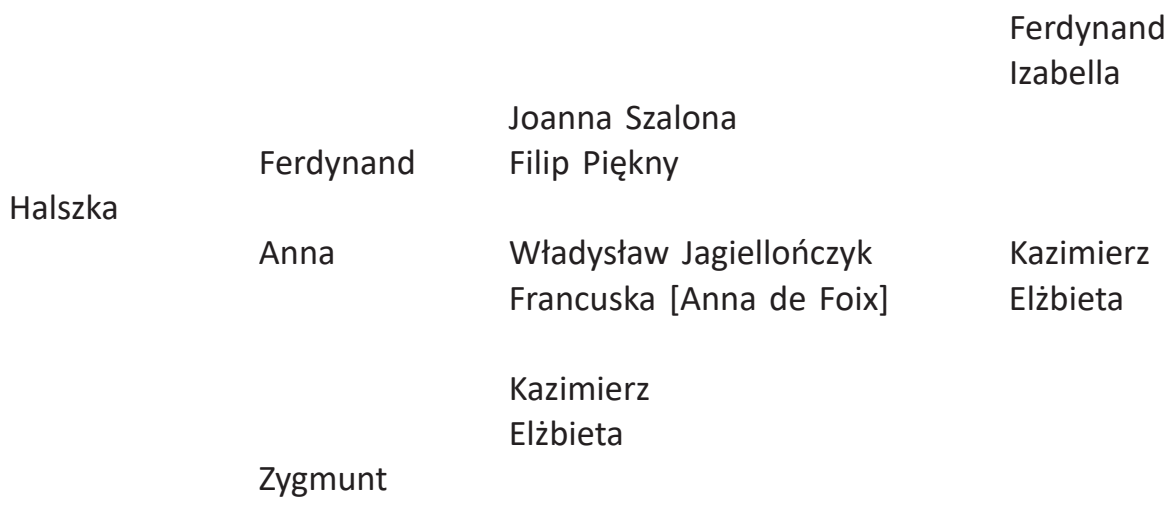


Zygmunt

Bona

$$
\begin{aligned}
& \text { Joanna d'Aragon } \\
& \text { Gian Galeazzo }
\end{aligned}
$$

1551

8 maja +

23 rusza pochód Rdest

23.VI. Sobótka

wylew Wisły

napad Tatarów

\section{Karta 13 v.}

Władysław

Kaz. Elżbieta

Anna (Elżbieta)

Elżbieta

Zabójstwo Martinuzziego

(Izabela wmieszana?)

\section{Karta 14}

Jerzy Radziwiłł 1480-1541

Mikołaj Rudy

Stanisław

Krzysztof Piorun

1559-1589

1547-1609

i Mikołaj Radziwiłł (1470-1522) Albert R.

\begin{tabular}{|c|c|}
\hline $\begin{array}{l}\text { Mikołaj Krzysztof Siero } \\
\text { 1549-1616 }\end{array}$ & $\begin{array}{l}\text { Jerzy, kardynał } \\
\text { 1556-1600 }\end{array}$ \\
\hline Krzysztof hetman pol. & Janusz \\
\hline $1585-1640$ & 1579-1620 \\
\hline & ż. Elżbieta Hohenz. \\
\hline Janusz hetman W.P. & Bogusław \\
\hline $1612-55$ & 1620-1669 \\
\hline & $\begin{array}{l}\text { Ludwika Karolina } \\
\text { za1/ Ludwikiem Hohenz. } \\
\text { 2/ ks. Neuburskim }\end{array}$ \\
\hline
\end{tabular}

Mikołaj Czarny (1515-1565)

\section{Karta 15}

1666. Jerzy Lubomirski, Jawney Niewinności Manifest [maszynopis]

„...Szczęśliwy pan, szczęśliwe państwo, gdzie pana z poddanymi, tę panom spokojność życia, nieśmiertelność sławy, pragnienie w poddanych wzbudzające i Rzeczpospolitą wieczną czyniące, wiążą vincula! Nieszczęśliwe te, gdzie więcej wagi ma 
strach niż miłość, gdzie bronią i mocą trony się gruntują, nie poddanych miłością, gdzie w sercach, w ustach, w postępkach czytać: oderint, dum metuant, i gdzie, pokazując przestrach i lękanie potencją, znajduje się niezbożna jedynowładnego panowania chciwość i ambicja".

1656. Fragment ze Ślubów Lwowskich Jana Kazimierza [maszynopis]

„....Gdy zaś z wielkim bólem serca widzę wyraźnie, że za łzy i ucisk włościan Sędzia Sprawiedliwy smaga Królestwo moje w ostatnim siedmioleciu powietrzem, wojnami i innymi klęskami, przeto przyrzekam i ślubuję, że po przywróceniu pokoju wraz ze wszystkimi stanami wszelkich użyję środków celem odwrócenia dalszych nieszczęść i postaram się, aby lud w moim Królestwie od wszelkich obciążeń i niesprawiedliwego ucisku uwolnić".

1797. Fragmenty z odezwy Dąbrowskiego do Polaków [maszynopis]

„...Polacy! Nadzieja nas jednoczy. Francja triumfuje - walczy ona za sprawę narodów... Stawajmy pod jej chorągwiami, są one chorągwiami honoru i zwycięstw. Legiony polskie formują się we Włoszech, na tej ziemi niegdyś świątyni wolności. Już oficerowie i żołnierze, towarzysze prac waszych i waszej waleczności, są ze mną, już organizują się bataliony. Przychodźcie, towarzysze moi, rzućcie broń, którą was nosić zmuszono! Walczmy za wspólną sprawę narodów, za sprawę wolności pod walecznym Buonapartem, zwycięzcą Włoch...".

1573. Uchwała sejmu elekcyjnego [rękopis]

„....A iż w Rzplitej naszej jest dissidium niemała in causa religionis christianae, zabiegając temu, aby się z tej przyczyny między ludźmi sedycja jaka szkodliwa nie wszczęła, którą po inszych królestwach jaśnie widzimy, obiecujemy to sobie spólnie pro nobis successoribus nostris in perpetuum sub vinculo iuramenti, fide, honore et conscientiis nostris, iż którzy jesteśmy dissidentes de religione pokój między sobą zachować, a dla różnej wiary i odmiany w kościelech krwi nie przelewać ani się penować confiscatione bonorum poczciwością carceribus et exilio i zwierzchności żadnej ani urzędowi do takowego progresssu żadnym sposobem nie pomagać; i owszem, gdyby ją kto przelewać chciał, ex ista causa zastawiać się o to wszyscy będziem powinni...".

\section{Karta 16 [rękopis]}

Masław?

I Unia Horodelska Sobór w Konstancji? (1413), Włodkowic

II Złote czasy, reformacja - arianie, XVI

III Skarga? Żółkiewski? Chodkiewicz? Opaliński? Herakliusz Lubomirski? XVII

IV Kuźnica Kołłątajowska

$\checkmark$ Legiony

141

Fabrica Litterarum Polono-Italica | 2020, nr 1 (2) 
VI Emigracja (1848)

VII 63

VIII 1905

Salon warszawski

IX 1918

Karta 17 [rękopis]

Paweł Włodkowic

1/ Tymieniecki, Moralność w stosunkach między państwami w poglądach Pawła Włodkowica, Przegląd Histor. 1919-20 (także tłumaczenia niektórych ustępów i bliższe wskazówki).

2/ Rozprawy opublikował: M. Bobrzyński, Starodawne prawa polskiego pomniki, tom V, Kraków 1878. (Najważniejszy jest tu Tractatus de potestate papae et imperatoris).

\section{Karta 18}

1631. S. Starowolski, Declamatio contra obtrectatores Poloniae [maszynopis] „...Dopuszczamy wolność sumienia, ponieważ przymuszać go nie można, a światło wiary przychodzi z niebios i rozszerza się li tylko przez nauczanie, pisanie i dysputy, według świętego zwyczaju dawnych ojców; a stąd ten skutek, że nigdzie u nas nie znajdziesz bezbożnych ateuszów, których pełno jest wśród tych, co się zowią katolikami, arcychrześcijanami, obrońcami wiary i pierworodnymi Kościoła, religię zaś objawiają jedynie szatą, a nie głębią serdecznego uczucia".

„...Prawa nie wedle woli królów, ale podług pożytku publicznego sami sobie obywatele stanowimy".

1413. Wstęp do Unii Horodelskiej [maszynopis]

„...Wiadomo wszystkim, że nie dostąpi zbawienia ten, kto nie będzie wspierany tajemnicą miłości, która zwaśnionych godzi, pokłóconych łączy, usuwa nienawiści, uśmierza gniewy i daje wszystkim pokarm pokoju, rozproszone zbiera, znękane krzepi, szorstkie wygładza, krzywe prostuje, wszystkie cnoty wspomaga, nikogo nie krzywdzi - tak, że ktokolwiek w jej ramiona się ucieka, znajdzie bezpieczeństwo i nie będzie się obawiał niczyjej napaści. Przez miłość prawa się tworzą, królestwa rządzą, miasta porządkują i stan Rzeczypospolitej do najlepszego końca dochodzi. Ona to wśród wszystkich cnót pierwsza miejsce zajmuje, a kto nią wzgardzi - wszelkie dobro utraci".

Statut Komisji Edukacyjnej - wstęp - zasady ogólne [rękopis]

Włodkowic

Sprawa chłopska: Skarga, Starowolski, K. Opaliński, Potocki

[słowo nieodczytane] - arianie

142

Fabrica Litterarum Polono-Italica | 2020, nr 1 (2) 
Karta 19, 20 i 21 [rękopis]

Unia Horodelska

Akt panów polskich

z d. 2 października 1413

(Oryginał znajduje się w archiwum nieświeskiem ks. Radziwiłłów)

W imię Pańskie, amen. Na wieczną rzeczy pamiątkę. Wiadomo wszystkim, że nie dostąpi zbawienia ten, kto nie będzie wspierany tajemnicą miłości, która zwaśnionych godzi, pokłóconych łączy, usuwa nienawiści, uśmierza gniewy i daje wszystkim pokarm pokoju, rozproszone zbiera, znękane krzepi, szorstkie wygładza, krzywe prostuje, wszystkie cnoty wspomaga, nikogo nie krzywdzi - tak że ktokolwiek w jej ramiona się ucieka, znajdzie bezpieczeństwo i nie będzie się obawiał niczyjej napaści. Przez miłość prawa się tworzą, królestwa rządzą, miasta porządkują i stan Rzeczypospolitej do najlepszego końca dochodzi. Ona to wśród wszystkich cnót pierwsza miejsce zajmuje, a kto nią wzgardzi, wszelkie dobro utraci. Przeto my, prałaci, panowie, szlachta i wielmoże królestwa polskiego, wszyscy razem i każdy oddzielnie, oznajmujemy wszystkim, komu wiedzieć należy, obecnym i przyszłym, którzy o niniejszym wiedzieć będą:

Ponieważ dążymy pobożnem życzeniem do tego, abyśmy spoczęli pod skrzydłami niezmiennej miłości, przeto złączyliśmy, zjednoczyli i brzmieniem niniejszego łączymy, równamy i jednoczymy domy i rody nasze, herby i klejnoty nasze ze szlachtą i bojarami ziem litewskich, którym były nadane, a pismem potwierdzone i umocnione, za naszem wstawiennictwem, wolności, przywileje, ekzempcje i łaski przez najjaśniejszego pana Władysława, z Bożej łaski króla polskiego itd., i księcia pana Aleksandra czyli Witolda, wielkiego księcia litewskiego. Z rzeczywistej miłości i braterskiego zjednoczenia dajemy im nasze herby, klejnoty i zawołania, któreśmy od rodziców i przodków naszych otrzymali, aby odtąd i na wieczne czasy mieli oni moc używania, korzystania z nich i posiadania, tak jakoby je od swoich przodków porządkiem urodzenia otrzymali. Niech jednoczy z nami miłość, niech uczyni równymi nam tych, których połączyła wspólność wiary, praw i przywilejów.

Obiecujemy w dobrej wierze, słowem naszem stałem i wiernem, pod czcią i przysięgą, nigdy ich, w żadnych przeciwnościach i potrzebach, nie opuszczać, lecz zawsze, przeciwko wszystkim zasadzkom ich nieprzyjaciół, udzielać rady i pomocy; przed wspomnianymi zaś panami naszymi łaskawymi, Władysławem, królem polskim, i Aleksandrem, wielkim księciem litewskim i ich następcami wszelką możnością i pilnością przyczyniać się, aby prawicę swej hojności dla nich otworzyli, nie przestawali mieć starania o ich pożytek i zasilali ich uprzejmymi względami łask swoich. To samo rzeczeni szlachta i wielmoże ziem litewskich jednakową wzajemnością pod wiarą i czcią, pod słowem wiernem i przysięgą powinni i nam czynić.

143

Fabrica Litterarum Polono-Italica | 2020, nr 1 (2) 
Prałaci, panowie i szlachta ziem litewskich nie zaczną żadnych z kimkolwiekbądź wojen bez zdania i rady naszej i naszych następców; my również, prałaci, panowie i szlachta królestwa polskiego, bez zdania i rady panów i szlachty ziem litewskich z nikim wojen nie rozpoczniemy.

Panowie i szlachta ziem litewskich oraz ich dziedzice i prawni następcy, nigdy, dopóki żyć będą, nie powinni opuszczać najjaśniejszych a łaskawych panów naszych, Władysława, króla polskiego, i Aleksandra, wielkiego księcia litewskiego, i ich prawnych następców, królów polskich i wielkich książąt litewskich, lecz owszem, pod wiarą, czcią i przysięgą, będą wiernie stali przy nich z życzliwością, posłuszeństwem, z wszelką pomocą i radą.

Aby zaś każdy z nich posiadł swój dom i tem wyraźniej były poznawane rozdzielność pojedynczych domów i różność herbów, aby to ustanowienie nasze z biegiem czasu przez zapomnienie nie zaginęło, oznajmujemy, że braterskim sojuszem na wieczne czasy połączone są, sprzymierzone, zjednoczone, na własność oddane i związane: - naprzód dom, herb, ród, klejnot i zawołanie szlachetnych Leliwa z domem i rodem szlachetnego Moniwida, wojewody wileńskiego; następnie -

Niech będzie wolno nazywać i korzystać z tych herbów, klejnotów i zawołań wszystkim im, razem z tymi, którzy z ich rodu prawnie zstępować będą, katolickiej tylko wiary, tak, jak by je od swoich prawnych przodków otrzymali.

Aby zaś wszystko powyższe większą trwałość i zabezpieczenie otrzymało, kazaliśmy, z jawnej wiadomości naszej, umocnić niniejsze naszemi pieczęciami. Działo się i dan w mieście Horodle na sejmie wielkim, w dniu 2 października roku pańskiego 1413-go.

(Unia Litwy z Polską.

Dokumenty i wspomnienia

zebrał

Henryk Mościcki.

Warszawa 1919 r.

g. i w.).

Karty 22, 23 [rękopis]

\section{Testament Zygmunta Augusta}

Warszawa, d. 6 maja $1571 \mathrm{r}$.

...A iż pod dusznem zbawieniem niczego więcej od Pana Boga nie żądamy i o nic umierając prosić pilniej nie będziemy, jedno abyśmy Rzeczpospolitą, jakośmy od przodków naszych wzięli, taką w cale i w pokoju i w dobrej sprawie oddali; o której dobro wedle największej możności naszej przez wszystek wiek panowania naszego staranieśmy czynili, jej dobro i zdrowie (bóg świadek) nad swoje zdrowie przekła-

144

Fabrica Litterarum Polono-Italica | 2020, nr 1 (2) 
dając; która to Rzeczpospolita niczem inszem w całości zachowania dłużej mieć nie może, jedno zgodą, miłością, spółecznością, jednością; bo jak ktoś po łacinie napisał: "Concordia res parvae crescunt discordia maximae dilabuntur"; i drugi także pisze: „Moc zjednoczona mocniejsza niż rozdwojona; przeto prosiemy i upominamy dla Pana Boga i dla dusznego zbawienia, aby wszyscy obywatele tak Koronni jako i Wielkiego Księstwa Litewskiego byli i żyli w jednej wierze chrześcijańskiej jednostajnie, jako Bóg Ojciec z Synem w jednostwie Ducha Świętego jeden jest. Potem też wszystkie Stanów a zwłaszcza Rad Duchowych i Świeckich, Rycerstwa, Szlachty i Mieszczan, poprzysięgając przez Boga żywego, przez miłość Rzeczypospolitej, prosiemy i upominamy, i zaklinamy, aby będąc obywatelami tak Korony jako i Wielkiego Księstwa Litewskiego byli jedną nierozdzielną Rzeczpospolitą wedle postanowienia Sejmu Lubelskiego tak dwuletniego, i poprzysiężenia, miłując się braterską miłością szczerze, prawdziwie, jako jednego ciała członki i jednej nierozdzielnej Rzeczypospolitej ludzie, nic jedni nad drugiemi zacnością i dostojeństwem sobie nie przywłaszczając, chcą-li, aby Pan Bóg, który będą jednym w jedności się kocha, jedność miłuje, pomnaża, wspomaga, długo te Państwa zjednoczone pomnażał i wspomagał. Przeto tym naszym Testamentem obiema Państwu: Koronie Polskiej i Wielkiemu Księstwu Litewskiemu dajemy i odkazujemy i zostawujemy miłość, zgodę, jedność, którą przodkowie nasi po łacinie Unią zwali i mocnemi spiski spólnie obywatelów obojego Państwa utwierdzonemi na wieczność ukrzepili; a którzy z tych dwóch narodów naród tę Unią od nas wdzięcznie przyjąwszy, mocno trzymać będą: tym to błogosławieństwo dajemy, aby ich Pan Bóg w łasce Swej, w szerokiem i spólnem panowaniu, we czci i sławie domowej i postronnej i we wszystkiem dobrem i potrzebnem przed inne narody wysławił i wywyższył; a który zasię naród niewdzięczen będzie i dróg do rozdwojenia będzie szukał: niechaj się boi gniewu bożego, który ma w nienawiści, jako Prorok mówi, przeklinając te, które sieją niezgodę pomiędzy bracią; za którem przekleństwem i gniewem bożym niczegoby się inszego nie bać, jedno doczesnego tu, a potem wiecznego zginienia, od którego racz Panie Boże zachować, a racz to $w$ tem obojgu Państwie utwierdzić, coś w niem przez nas sprawit, racz oboi ten lud w Państwie utwierdzić, coś w niem przez nas sprawił, racz oboi ten lud w jedności spokojnej, w niezmyślonej miłości wiecznie chować...

(Al. Przezdziecki, Jagiellonki polskie, Kraków 1868)

((Unia Litwy z Polską - Dokumenty i wspomnienia - zebrał H. Mościcki, Warszawa, Geb. i Wolff - 1919))

\section{Karta 24 [rękopis]}

Bibliografia polska Estreichera (Wiek XV-XVIII)

1/ Narzekanye królowy na nyszczescye po smyerci. Drukowano w Krakowie przez (na odwrocie tytułu S. Barbara). Jestto dyalog m. Barbarą Radziwiłłówną 
bolejącą nad niedolą swojego losu a szczęściem chwalącem się ze swoich darów. Druk zapewne w 1531 zaraz po śmierci królowej. Estreicher nie podaje, gdzie się znajduje.

2/ Oratio de inauguratione Ser. Reginae Poloniae Barbarae autore Germano quodam equite. Crac. ex off. Hieron. Scharffenberg 1550. [Ossolineum]

\section{Karta 25 [rękopis]}

Materiały do Barbary Radziwiłłówny z bibliografii historii Polski Finkla

1/ Niemcewicz J. U. - Zbiór pamiętników. T. I i IV (listy Zygm. do Barbary kr. pol. i do Mikołaja Radziwiłła 1547-1559).

BUW sygn.: 72017; 4.26.5.7.; 4.27.5.5.

2/ Cztery listy królowej Barbary do brata jej Mikołaja Radziwiłła pisane. Atheneum 1842. T. V. BUW: 2g.4.3.1.

3/ Trzy listy Zygm. Augusta do królowej Barbary, do St. Łaskiego i Mikołaja Radziwiłła. Dziennik Warszawski 1827, t. VII. BUW: 015801 (1827).

4/ Listy Koszuckiego St., Spytka Jordana, Podlodowskiego do Mikołaja Radziwiłła o zdrowiu królowej Barbary itd. Dziennik Warsz. 1826. T. V-VI. BUW: 015801 (1826).

5/ Cricius Andreas (Krzycki) - Carmen in conn. Sigismundi et Reginae Barbarae. Crac. 1512. Acta Tomiciana (do r. 1531). BUW: 25143 i Czytelnia.

6/ tegoż autora: Deploratio mortis Barbarae reginae. Crac. 1515. BUW: j.w. i 8.11.5.19. (Corpus Poetarum Pol. Krzyckiego).

7/ Próbki dowcipnisiów XVI w. (o Zygm. Auguście, o Barbarze, opis grodu wileńskiego 1550, o Bonie). [Narbutt, Dzieje Litwy] t. IX. BUW: 4.2.5.14. (t. IX).

8/ Narzekanye królowej na nyszcześcije po śmierci. Kr. 1551.

Tiezinensis, Oratio inter exegniarum solemnia reginae Barbarae.

Rom. 1551. (Druki współczesne) [Ossolineum]

9/ Szczątki pałacu królowej Barbary. Przyjaciel Ludu, Leszno. 1840/41 t. VII. BUW: 2g..4.1.

10/ Zgoda o Barbarę i koronacya w r. 1550. Przyj. Ludu 1839. t. VI. BUW: 2g.25.4.1. (1839).

11/ Siemieński L. H. - Cień królowej Barbary. j.w. 2g.25.4.1. (1835) t. II.

12/ Siemieński L. H. - Wieczornice. Wilno 1854. T. I. (popularne) BUW: 17.6.3.25.

13/ Baliński M. - Dopisek o szkicu K. Szajnochy. [Studja hist. Wilno 1856] BUW: 4.25.4.11

14/ Wójcicki K. Wł. - Zygmunt August i Barbara Radziwiłłówna. (Kłosy. XIV). BUW: 07712 i 4.11.3a.1.

15/ Przeździecki Al. - Zygm. August i Barbara. Tyg. Ilustr. 1872. IX. BUW: 4.11.1a.1.

16/ Tomkowicz St. - Barbara Radziwiłłówna. Biesiada Lit. 1882. BUW: 2g.15a.1.1.

146

Fabrica Litterarum Polono-Italica | 2020, nr 1 (2) 
17/ Wodziński A. - Barbare Radziwill. Nouv. Revue. Paris. LXXVIII. BUW: 014532 (1892).

1/ Listy Marcina Zborowskiego do Jordana Spytka. Przyj. Ludu, Leszno 1837. IV.

2/ Oratio de inauguratione Barbarae... Crac. 1550 (druk współczesny)

3/ Popow N. - Barbara żona Zygm. Aug. [Goniec ruski, Moskwa 1857]

4/ Bartoszewicz J. - Charakter Barbary Radziwiłłówny. Kalendarz Ilustr. dla Polek. Warszawa 1864.

5/ Ziemięcka E. - Kilka słów z powodu artykułu Bartoszewicza. j.w.

6/ Tomkowicz St. - Barbara Radziwiłłówna w historii, rzeczywistości i poezji. Przegląd Polski 1875. I - II.

Tych pozycji nie ma w BUW i prawdopodobnie w [Bibliotece] Narodowej również.

\section{Karta 26}

Itinerarium Zygmunta Augusta ze zwłokami Barbary [maszynopis]

Baliński Michał - Pamiętniki o królowej Barbarze żonie Zygm. Augusta. W Warszawie 1840, t. II (str. 288-308)

BUW - sygn.: 4.25.6.19.

„...Gdy na koniec zbliżył się czas wyjazdu naznaczony od króla, dnia 25 maja w poniedziałek, nazajutrz po świętej Trójcy, odbył się uroczysty kondukt zwłok królowej z zamku do kościoła katedralnego w Krakowie, przez biskupa krakowskiego i drugiego jeszcze, którego nazwiska dzieje nie wymieniły, w obecności żałosnego króla, dworu i rad koronnych. Tam dopiero odprawiły się solenne exekwie za duszę zmarłej, po zakończeniu których nad samym wieczorem zwłoki złożono do kolebki [karety] i nastąpiło ich uroczyste wywiezienie do Litwy z największą jaka tylko być mogła okazałością. Piotr Kmita wojewoda krakowski i Jan Spytek Tarnowski herbu Leliwa, wojewoda sieradzki, szli z obu stron woza żałobnego, za którym postępował August otoczony panami, radą i dworem; biskupi i całej stolicy duchowieństwo poprzedzało ten smutny pochód. W pewnej dopiero odległości za miastem ci wszyscy, którzy nie mieli towarzyszyć królowi w podróży, pożegnawszy go wrócili do miasta, a Zygmunt August konno udał się za powozem unoszącym drogie szczątki ukochanej Barbary w długą i daleką podróż. Przy królu prócz marszałka Radziwiłła, kasztelana Maciejowskiego i innych panów i dworzan, znajdował się ksiądz Jan Przerębski herbu Nowina, podkanclerzy koronny, później biskup Chełmski: za ciałem zaś królowej jechały z pań dworskich między innemi, wojewodzina Połocka (żona Stanisława Dowojny), wojewodzina Witebska (żona Stanisława Kiszki, herbu Dąbrowa) i stara Kiejżgałłowa, matka stolnika W. Litew- 
skiego. (Nie znajdujemy tylko nigdzie odtąd śladu, gdzie się podział ów poufały powiernik Mikołaja Radziwiłła, a sługa wierny i domownik Barbary, uczony Koszucki. Godzi się nam jednak wątpić, żeby go wyprawiono rolę orać do Koszut, czego się sam lękał; zapewne musiał równie z innemi odprowadzać zwłoki swej pani a potem łask Zygmunta Augusta doświadczać).

Zaraz w Broszowicach spotkał król komornika dworskiego Lewona, niosącego z Wilna odpowiedź od szwagra „....Mikołaja Radziwiłła, który namawiał króla do pochowania Barbary w Krakowie - list ten przytacza Baliński in extenso, jak również odpowiedź króla z 26 maja pisany z Kiźliczy (Kościelec, wieś kościelna za Proszowicami)...".

Tak tedy August, zapewniając przez wieczną pamięć dla Barbary, niezmienne względy dla domu Radziwiłłowskiego, prowadził do Wilna z ciężkim żalem i smutkiem zwłoki swej żony, mimo przełożenia panów koronnych i przeciwne zdanie jej braci. W całej tej drodze aż do uwielbienia wszystkich w miłości małżeńskiej niezrównany, cześć zwłokom Barbary oddawał. Wszystkich pisarzy najgodniejszych wiary jednogłośne podania (Rysiński MSS. Orzechowski Anna IV. Warszewicki Parall. Lib.II) świadczą, że ani na chwilę nie odstępując kolebki z ciałem, tuż za nią ciągle jechał konno w głębokim smutku pogrążony, a skoro tylko orszak żałobny do jakiej wsi lub miasta się zbliżał, Zygmunt August z konia zsiadał i pieszo postępował. Żadna go od tego niepogoda, żadne przeszkody odwieść ani razu nie mogły. Trumnę z ciałem na noc składano na marach w kościele, a proboszcz miejscowy lub inni duchowni, jacy się tam znaleźli, zwykłe exekwie przy zmarłej odśpiewywali. Czarnej maści konie ciągnęły powóz ze zwłokami Królowej, a że w ciągu tej długiej podróży podczas mocnych upałów zaczynającego się lata jedne i też same dla zbytecznego znużenia wytrzymać nie mogły, król kazał zastępować innemi, kupując je chociażby najwyższą ceną. Takim sposobem odbywając drogę swą, Zygmunt August przybył do Łukowa i stamtąd krótkim listem zawiadomił wojewodę Trockiego, że zgodnie z myślą jego zamierza pochować Barbarę obok pierwszej żony swej Elżbiety Austryaczki w kościele katedralnym św. Stanisława w Wilnie" (Baliński przytacza wyjątek listu królewskiego z 7 czerwca z Łukowa. Wszystkie listy Zygmunta Augusta cytuje ze Zbioru pamiętników Niemcewicza - T. 1, s. 390-484).

(17 czerwca staje Zygmunt August w Mostach nad Niemnem w Grodzieńskiem, 20 mil od Rudnik, skąd znów pisze list do Mikołaja Radziwiłła z instrukcjami co do uroczystości żałobnych w Rudnikach, królewskiej rezydencji myśliwskiej odległej o 4 mile od Wilna).

„Już w Mostach spotkał króla jeden z pierwszych urzędników krajowych, Stanisław Kieżgałł stolnik Litewski, poczem Zygmunt August, mając jeszcze około dwudziestu mil drogi do Rudnik przez Rożankę, Szczuczyn i Wasiliszki w powiecie lidzkim, udał się w podróż do Okielnik, miasta królewskiego, gdzie dwór swój nad rzeką Mereczem posiadał. Tam stanąwszy z ciałem Barbary, witany był od Mikołaja 
Radziwiłła Czarnego, marszałka i kanclerza W. Litewskiego, którego też w owem miejscu na okazanie przychylności swej i na wynagrodzenie zasług $w$ usłudze publicznej poniesionych wyniósł na dostojność wojewody Wileńskiego.

Zdaje się, że około 20 czerwca zjechał król do Rudnik, gdzie znalazł już przybyłych na jego spotkanie niektórych z panów rad Litewskich. Zwłoki Barbary podług woli Augusta zamknięte $w$ powozie, stanęły przed głównym domem rezydencji myśliwskiej w Rudnikach, w którym na górnych komnatach pomieściły się wszystkie kobiety należące niegdyś do dworu zmarłej królowej. August i wszyscy przy nim będący inne budowy na mieszkanie zajęli. Dwa dni wypoczywał król z długiej podróży, a tymczasem w Wilnie kończono wszystkie przygotowania do uroczystego pogrzebu. Nie mamy dotąd z żadnych źródeł wiadomości o szczegółach tego smutnego obrzędu, podług wszelkiego jednak podobieństwa do prawdy, odbył się on 23 czerwca w wilią św. Jana. Wszyscy dziejopisowie zaświadczają w ogólnych wyrazach o wspaniałości pogrzebu królowej, ale potomność przekonana tą wierną o całej mocy przywiązania Zygmunta Augusta do żony, łatwo sobie wystawić zdoła, że w tak żałosnych obrządkach nic nie zostało zaniedbanem, coby tylko czci i miłości dla zgasłej Barbary dowieść mogło. Po skończeniu konduktu i żałobnego nabożeństwa drogie jej zwłoki, z wielką żałością obecnego zawsze króla, pochowano w grobie kaplicy św. Kazimierza, przy kościele katedralnym Wileńskim św. Stanisława, obok pierwszej jego żony Elżbiety w Wilnie zmarłej. A chociaż król składał je tymczasowo tylko, mając zamiar pogrześć ostatecznie w założonym od siebie kościele św. Anny, niedługo jednak potem sprowadzeni do Wilna dwaj znakomici rzeźbiarze włoscy, Jan Maria i Jan de Senis, w tymże kościele św. Stanisława wznieśli z kosztownych marmurów wspaniałe nagrobki dla Barbary i pierwszej żony Elżbiety. Następcy Zygmunta Augusta chociaż skończyli budowę kościoła św. Anny, ozdobiwszy go wszystkiemi wdziękami stylu gotyckiego, nie wykonywali jednak życzeń Augusta: i zwłoki Barbary zostały tam, gdzie je naprzód miłość małżonka złożyła.

Starowolski zachował nam następujący napis na jej pomniku położony:

Barbara que tegitur tumulo Regina sub isto

Augusti conjunx, altera Regis errat.

Commoda multa tulit multis, incommoda nulli,

A qua se laesum dicere nemo potest.

Immatura obiit decima trieteridi capta

Bis viduos fatis linquere iussa toros.

Occidit ante diem, et quanvis anno illa fuisset,

Diceret Augustus, occidit ante diem". 
Karta 27 [maszynopis]

Polski Słownik Biograficzny. Tom 1 (Wł. Pociecha: Barbara Radziwiłłówna)

1/ Orzechowski St., Annales (przytem S. Górskiego Vita P. Kmithae) wyd. Działyński T., P.1854. B-ka Narodowa, sygn. II.192.152

2/ Graziani A.M., De vita J. F. Commendoni, Paryż 1669, 112-115, I 79; nie ma ani w B-ce Narod. ani w BUW

3/ Baliński M., Pamiętniki o królowej Barbarze. W. 1837, 1840 I-II (2 wyd. w Pismach historycznych. W. 1843, I-II. B-ka Uniw. sygn.: 4.25.6.19 [obok zapisek Iwaszkiewicza fioletowym atramentem: mam]

4/ Baliński M., Dopełnienie pamiętników o królowej Barbarze. „Studja hist.” Wilno 1856. B-ka Narod., sygn.: II.69.860

5/ Lachowicz S. A., Listy oryg. Z. Augusta. Wilno 1842. B-ka Uniw., sygn. 4.28.6.10.

6/ Szajnocha K., Barbara Radziwiłłówna. „Szkice hist.” Lw. 1858. I. wyd. 2. BUW. sygn.: T. 10.5/4; 8.4.9.37; 4.12.6.28 (inne wyd.)

7/ Kotłubaj Edward, Galerja nieświeska portretów radziwiłłowskich. Wilno 1857. BUW. sygn. 4.25.2.11.

8/ Bartoszewicz J., art. o Barbarze w enc. org. Czytelnia BUW [obok zapisek Iwaszkiewicza fioletowym atramentem: mam]

9/ Przeździecki A., Barbara Radziwiłłówna, „Jagiellonki polskie w XVI wieku”, I, V. Kr. 1868, 1878. BUW: 18.35.12.17./1/5; 4.2.5.10./1/5

10/ Tomkowicz S., Barbara Radziwiłłówna u historyków w rzeczywistości i w poezji. Kr. 1875. Nie ma ani w BUW ani w B.N.

11/ Diaryusz sejmu piotrkowskiego 1548, wyd. Szujski J. (Scrip. rerum pol.). Kr. 1872. Czytelnia BUW

12/ Finkel L., Charakterystyka Z. Augusta. Lw. 1888. Nie ma ani w BUW ani w B.N.

13/ Finkel L., art. o Barbarze w W. Encykl. II. Czytelnia BUW. (W artykule tym Finkel podaje szereg nazwisk współczesnych panów polskich i osób występujących wtedy publicznie)

14/ Korzeniowski J., Nieznane wiersze polskie i łacińskie 1548-1551. Kr. 1886. B.N. sygn.: 29821 / Hor.

\section{Karta 28 [maszynopis]}

15/ Korzeniowski J., Orichoviana 1543-1566. Kraków 1891 (Bibl. Pis. pol. nr 19). BUW 4.7.3.1/19; 4.21.4.44

16/ Pułaski F., Nieznane listy B. Radziwiłłówny,. W. 1906. BUW 4g.23.2.383.

17/ Baranowski J.T., Z dziejów feudalizmu na Podlasiu. W. 1907. BUW sygn. 83031

150

Fabrica Litterarum Polono-Italica | 2020, nr 1 (2) 
18/ Wierzbowski T., Wiersze polityczne i przepowiednie, satyry i paszkwile z XVI w. W. 1907 (Bibl. zap. pet. i proz. pol. XVI-XVIII w. nr 24. BUW 18.32.4.3.(24)

19/ Orzechowski S., Fidelis subditus (w red. 2 z r. 1548), wyd. Saenger i Wierzbowski T., W. 1908 (Bibl. zap. pet. i proz. pol. XVI-XVIII w., nr 25). BUW 18.32.4.3.(25).

20/ Bezzenberger A., Berrichte u. Briefe... Asverus v. Brandt, Konigsberg 1911, z. 3; nie ma ani w BUW ani w B.N.

21/ Kolankowski L., Z. August, Lw. 1913; BUW 4g.6b.8.58(VII-1)

22/ Bogatyński W., Z dziejów małżeństwa Z. Augusta z Barbarą (Rozpr. Wydz. Hist.-Fil. PAU. Kr. 1916 ser. II. T. 34; BUW 82806

23/ Bartoszewicz K., Radziwiłłowie. Kr. 1928. Nie ma w BUW i w B.N.

24/ Kolankowski L., Dzieje polityczne Polski Jagiellońskiej. W. 1932. BUW sygn. 9356

25/ Morstin L.H., O pierścień Barbary. „Wiad. Lit.” nr 49 (466) z 20 XI 1932; BUW sygn. 05886 i 05762.

Z źródeł nieogłoszonych drukiem podstawowe znaczenie ma oryg. korespondencja poufna (autografy) M.R. Czarnego z Rudym i królem odnaleziona przeze mnie w jednym ze zbiorów prywatnych (część tej korespondencji znana była z kopii z XIX w. w rkp. Muz. ks. Czartoryskich w Krakowie nr 2833); Archivio di stato w Modenie B1. B2 (Koresp. Valentiniego, dep. Negrisolliego); Bibl. Publ. w Leningradzie coll. aut. nr 62; H.H. u. Staatsarchiv w Wiedniu, Pol. Fasc. III i IV; Arch. Gł. w W-wie, Rach. król. Oddz. I, nr 358, f. 13V, Metryka lit. (odpisy) i ks. 28 (oryg.); Bibl. Kórnicka, rkp. 229, II 103, 221, II 95, 240, II 114; Muz. ks. Czart. W Krakowie; rkp. 247, 283, 821, 1599. Kom. Hist. PAU, Teki Królewieckie.

Wł. Pociecha

Karta 29 [maszynopis; od lewego dolnego rogu do górnego prawego napis czerwonym atramentem: Pogrzeb Królowej]

Dnia ósmego maja roku 1551-go zmarła na zamku wawelskim w Krakowie królowa Barbara.

Królowa Barbara zmarła na zamku w Krakowie dnia ósmego maja roku 1551.

W dzień świętego Stanisława roku pańskiego 1551 królowa Barbara zmarła na zamku wawelskim w Krakowie.

Królowa Barbara Radziwiłłówna zmarła na zamku w Krakowie w sam dzień świętego Stanisława roku pańskiego 1551.

Dnia ósmego maja roku 1551 królowa Barbara zmarła na zamku wawelskim w Krakowie.

W roku 1551 dnia ósmego maja królowa Barbara umarła na zamku w Krakowie.

Królowa Barbara zmarła na zamku wawelskim w Krakowie dnia ósmego maja 1551 roku.

151

Fabrica Litterarum Polono-Italica | 2020, nr 1 (2) 
Królowa Barbara zmarła na zamku w Krakowie w dzień świętego Stanisława 1551 roku.

Królowa Barbara umarła na zamku w Krakowie dnia 8 maja 1551 roku. [zdanie obrysowane ramką]

6 czerwca 1949 [odręcznie czerwonym atramentem]

Karta 30 [list pisany odręcznie czarnym atramentem]

Toruń 11.6.1949

Na list z 7 czerwca odpowiadam natychmiast po otrzymaniu go, przystępując od razu ad rem. Ostatnim wyrazem nauki w znanej sprawie jest artykuł znakomitego znawcy tych czasów, dra Wład. Pociechy (w Bibliotece Jagiellońskiej w Krakowie, autora wielkiej pracy o Bonie - dotychczas ukazał się t. 1) w Polskim Słowniku Biograficznym (jest w Warszawie w każdej bibliotece) w tomie I str. 294-298. Tam też podane są wszystkie, dotyczące Barbary, opracowania. Proszę więc zapoznać się z powyższą rozprawką - a znajdzie Pan aż nadto materiału do swego zamierzonego pięknego utworu. Zmarła Barbara 8 maja - u mnie jest błąd drukarski. Co do tła, to proszę przeglądnąć moją książkę: Zygmunt August, stronice o małżeństwie Z. A. z Barbarą. Ponadto warto przeglądnąć kilka z cytowanych w Słowniku na str. 298 rozpraw oraz przerzucić roczniki Reformacji wydawanej przez prof. Kota w Krakowie w latach 1920. Nie zawadziłoby też zaglądnąć do Brücknera Dziejów kultury oraz Kubali, St. Orzechowskiego. Proszę mi wybaczyć, że nudzę i trwożę Pana tą „literaturą" - ale chciałbym, by to arcydzieło Pańskiej duszy, które już widzę i odczuwam, było oparte na wszelkich danych wyobraźni, serca i rozumu. Sam pomysł jest przepiękny. Nie wątpię, że i zrealizowanie go da nam nowy klejnot dobyty z głębi duszy.

Łączę uścisk dłoni

Lud[wik] Kolankowski

Karta 31 [list w rękopisie]

29 VII 1949

Szanowny Panie,

Przesyłam Panu bibliografię do Barbary Radziwiłłówny wypisaną z Pol. Słownika Biograficznego z zaznaczeniem co znajduje się w Bibliotece Uniw. (BUW), a co w Bibl. Narodowej (B.N.) i z podaniem sygnatur. Niestety kilku pozycji nie ma w żadnej z tych bibliotek.

Poza tą bibliografią Pociechy znalazłam jeszcze w Bibl. Uniw. kilka pozycji, które też podaję na wszelki wypadek gdyby się Panu przydały:

1/ Ziembicki Witold - Barbara Radziwiłłówna w oświetleniu lekarskim. Lw. 1935.

2/ Barbara Radziwiłłówna królowa polska żona Zygm. Augusta. Przez R.J. Warszawa 1861. BUW - sygn.: 4g.23.2.249.

152

Fabrica Litterarum Polono-Italica | 2020, nr 1 (2) 
3/ Barbara Radziwiłłówna. Romans hist. z franc. oryg. na język polski przetłumaczony. W 2 częściach z 2 kopersztychami. Wrocław 1821. BUW - sygn.: 17.5.2.7.

4/ Napis nad grobem zacney królowej Barbary Radziwiłłówny niegdy będącey królowy polskiey. W Krakowie 1558. BUW - 28.1.8.28.

Wypisałam też kilkanaście pozycji z Bibliografii Estreichera i z Bibliografii historii pol. Finkla, których nie podaje Pociecha, ale ponieważ nie zdążyłam ich sprawdzić w katalogach - na razie ich nie wymieniam.

Innych materiałów w tym tygodniu zebrać nie zdążyłam, gdyż miałam dużo pracy przed urlopem, a po południu nasza biblioteka jest w okresie wakacji zamknięta.

Postaram się zaraz po przyjeździe z urlopu dostarczyć Panu więcej materiału (przed 10 września).

Pozostaję z wysokim szacunkiem

Zofia Zarembianka

\section{Karta 32}

Drukowane zaproszenie o treści:

Ministerstwo Szkolnictwa, Nauk i Sztuk

Republiki Czechosłowackiej

oraz

Ministerstwo Kultury i Sztuki Rzplitej Polskiej

ma zaszczyt prosić na otwarcie wystawy

"Czechosłowacka książka w służbie pokoju i postępu"

które odbędzie się dnia 21 października 1950 roku

o godzinie 12 w Politechnice Warszawskiej

Na odwrocie zaproszenia ręką Iwaszkiewicza:

Przeczytałem:

Pociecha: Królowa Bona

Pociecha: artykut w St. Biogr.

Morawski: Czasy zygmuntowskie

Halecki: Dzieje Unii Jagiellońskiej

Przeździecki: Jagiellonki polskie

„Wiadomości”: Jan Kochanowski

Karta 33 [rękopis listu]

$25 \times 1949$

Szanowny Panie,

zwlekałam trochę z przesłaniem dalszego materiału, gdyż spodziewałam się, że może zajdzie Pan osobiście do Biblioteki i miałam nawet u siebie trochę książek

153

Fabrica Litterarum Polono-Italica | 2020, nr 1 (2) 
specjalnie dla Pana odłożonych, m.in. takie dosyć ciekawe tablice chronologiczne, które może jeszcze kiedy przy okazji zechce Pan zobaczyć.

Przesyłam Panu itinerarium Zygm. Augusta ze zwłokami Barbary, przepisane z Pamiętników Balińskiego. Jest to najbardziej szczegółowy opis w porównaniu z wszystkimi innymi przejrzanymi przeze mnie kronikami i pamiętnikami.

Co do r. 1551, to udało mi się ustalić tylko trzy fakty ściśle z nim związane, mianowicie:

1/ we Francji urodziny Henryka III, syna Henryka II i Katarzyny de Medicis, późniejszego króla polskiego, Henryka Walezjusza;

2/ Sobór Trydencki (druga faza: 1551-1552, bo w ogóle trwał z przerwami od 1545-1563), który ostatecznie potępił reformację i umocnił stanowisko papieża. Wreszcie trzeci ważny fakt, w Ameryce Połudn. - założenie uniwersytetu w Limie, stolicy Peru, w r. 1551 (w Meksyku pierwszy uniwersytet założono w 1553 r.). Administratorem z ramienia Hiszpanii był wtedy don Louis de Velasco (1550-1564), który protegował Indian czuwając nad ich materialnym i intelektualnym rozwojem. Poza tym w Ameryce Połudn. - dalsze postępy kolonizacji hiszpańskiej, wprowadzanie ich administracji państwowej itp., do Portugalii należy jedynie Brazylia (Barbagelata M., Histoire de l'Amerique Espagnole. Paris 1936. sygn. BUW: 41876). Gdyby Pan chciał więcej szczegółów dotyczących właśnie Ameryki Połudn. - mogłabym podać odpowiednią lekturę. Źródła są przeważnie w języku hiszpańskim, literatura w języku angielskim.

Poza tym sytuacja w poszczególnych państwach przedstawia się w tym okresie następująco: we Francji - Henryk II, który w walce z Karolem V ces. rzymskim i ówczesnym władcą Hiszpanii, zdobył 3 ważne miasta, 3 biskupstwa lotaryńskie: Metz, Toul i Verdun. Początki walk z Hugonotami. W Niemczech - walki religijne zakończone pokojem w Augsburgu w 1555 r. Przed tym jeszcze w roku 1552 Maurycy ks. saski w przymierzu z Henrykiem II zmusił Karola V do traktatu passawskiego, gwarantującego wolność religijną protestantom niemieckim. We Włoszech - rozbicie i poddanie wpływom francuskim i hiszpańsko-austriackim (Filip II, syn Karola V, otrzymał Neapol i Mediolan), we Florencji Medyceusze. W Anglii - panowanie Elżbiety, w Szkocji - Maria Stuart, w Hiszpanii - Karol V.

O ile zależałoby Panu na dalszych poszukiwaniach, proszę uprzejmie o zawiadomienie mnie o tym i o odpowiednie wskazówki, a zawsze chętnie w miarę możności postaram się ułatwić Panu te żmudne poszukiwania biblioteczne.

Z głębokim poważaniem

Zofia Zarembianka

154

Fabrica Litterarum Polono-Italica | 2020, nr 1 (2) 


\section{Bibliografia}

Galıs Adam (1934): Rozmowa z J. Iwaszkiewiczem. „Tygodnik Ilustrowany” 1934, nr 49

(9 XII 1934).

IWASZKIEWICZ Jarosław (1977): Podróże do Włoch. Warszawa.

IWASZKIEWICZ Jarosław (1983): Podróże do Polski. Warszawa.

IWASZKIEWICZ Jarosław (2007): Dzienniki 1911-1955. Oprac. i przypisy A. i R. Papiescy.

Wstęp A. Gronczewski. Warszawa.

IWASZKIEWICZ Jarosław (2009): Listy do córek. Słowem wstępnym poprzedziły

M. Iwaszkiewicz i T. Markowska. Oprac. A. i R. Romaniukowie. Warszawa.

IWASZKIEWICZ Jarosław, KĘPIŃSKI Wiesław (2014): Męczymy się obaj. Korespondencja

z lat 1948-1980. Wstęp R. Papieski, opracowanie A. i R. Papiescy. Warszawa.

\section{Abstract \\ Il funerale della regina di Jarosław Iwaszkiewicz - edizione del testo}

Il saggio si basa principalmente sul manoscritto inedito del romanzo di Jarosław Iwaszkiewicz dedicato a Bona Sforza, Il funerale della regina, su cui egli ha lavorato tra il 6 giugno 1949 e il 1953. L'autore presenta le fonti che hanno dato origine al libro e il modo in cui si è sviluppato. Inoltre, tutti i documenti scoperti e raccolti da Iwaszkiewicz nel corso della lavorazione al romanzo sono inclusi nel libro: appunti, le nove versioni della prima frase del romanzo, le lettere di Ludwik Kolankowski e Zofia Zarembianka, le quali hanno fornito a Iwaszkiewicz fatti concreti. La conclusione del saggio ci illustra che la grande quantità di documenti raccolti da Iwaszkiewicz, invece di aiutarlo, lo ha paralizzato, rivelando così la natura della sua scrittura.

Parole chiave: Bona Sforza, Jarosław Iwaszkiewicz, Stawisko, Barbara Radziwiłłówna, manoscritto 